\title{
NULIDADE DA ALIENAÇÃO FIDUCIÁRIA QUANDO 0 EMPRÉSTIMO NÃO SE DESTINA À AQUISIÇÃO DO BEM DADO EM GARANTIA
}

\author{
Manoel Caetano Ferreira Filho \\ Prof. Adjunto do Depto de Direito Civil e Proces- \\ sual Civil da Fac. de Direito do Setor de Ciências \\ Jurídicas da UFPR.
}

1. O Tribunal de Justiça do Rio Grande do Sul, no acórdão proferido na apelação cível no 587007485 , de 17 de setembro de 1987, em que foi relator o eminente Desembargador Galeno Lacerda*, desvelou doutrina com a qual manifestamos, desde logo, nossa total concordância, ensejando oportunidade para a presente reflexão.

Tratava-se de pedido de restituição de bens dados em alienação fiduciária, como garantia de contrato de repasse de empréstimo externo, com fundamento no art. 70 do Decreto-Lei no 911/69, eis que já havia sido decretada a falência do devedor.

Considerando que o empréstimo não se destinava à aquisição dos bens dados em garantia, mas sim a "financiamento de capital fixo e/ou de movimento", a Câmara, unanimemente, julgou nula a cláusula que previa a alienação fiduciária, por ter sido pactuada "em fraude à lei, a simular, repito, penhor com pacto comissórió antecipado".

2. Tem sido freqüente, como noticia o próprio acórdão, o ușo da alienação fiduciária, por parte dos bancos, para garantia de empréstimos não destinados à aquisição dos próprios bens objeto da alienação.

Esta prática, contudo, traduz verdadeira deturpação do instituto, ferindo os dispositivos legais que o disciplinam, bem como o art. 765 do Código Civil.

A alienação fiduciária foi instituída entre nós com o declarado objetivo de facilitar a concessão do crédito ao consumidor, desempenhando "função relevante como garantia nas operações

\begin{tabular}{llllll}
\hline R. Fac. Direito Curitiba & a. 25 & n. 25 & p. 119-124, 1989 & 119
\end{tabular}


feitas pelas financeiras para financiamento ao usuário de bens de consumo ou de produção". 1

Ao propor, perante o Senado Federal, subemenda ao projeto de lei que disciplina o mercado de capitais, no sentido de aprimorar 0 artigo que instituía a alienação fiduciária, o Senador Jefferson Aguiar apresentou longa justificativa, em que fazia o seguinte esclarecimento: "presente emenda visa a enriquecer nosso direito com instituto jurídico que possibilite a garantia dos empréstimos para aquisição de mercadorias e bens, principalmente dos financiamentos das importações, dando ao mutuário a possibilidade de ficar na posse de tais bens e mercadorias". ${ }^{2}$

Como se vê, o objetivo foi munir o financiador de uma garantia idônea, sem, no entanto, retirar do mutuário a posse do bem adquirido como financiamento Além de dar ao credor uma garantia fortíssima (a propriedade, ainda que resolúvel, do bem dado em garantia), facilita a aquisição. por parte do comprador, que dá em garantia a própria coisa adquirida.

Esta finalidade revela a causa do negócio jurídico.

A doutrina, até com o escopo de distinguir o instituto em análise de outras figuras afins, ressalta essa sua característica peculiar: o bem alienado dever ser aquele adquirido com $0 \mathrm{em}$ préstimo que a alienação visa a garantir.

Conceituando o instituto, escreve FRAN MARTINS: "consiste a alienação fiduciária em garantia na operação em que, recebendo alguém financiamento para aquisição de bem móvel durável, àliena esse bem ao financiador, em garantia do pagamento da dívida". ${ }^{3}$ Ressalta, assim, nas palavras "esse bem", que a garantia deve recair sobre o mesmo bem adquirido com o financiamento e não sobre outro qualquer.

E incompatível, pois, com a alienação fiduciária que a coisa dada em garantia seja outra que não aquela adquirida com o empréstimo que está a garantir.

3. Na verdade, o que se verifica nesses contratos é a instituição de penhor, mascarado na forma de alienação fiduciária, com antecipação de pacto comissório vedado expressamente pelo àrt. 765 do Código Civil.

Com efeito, dar o devedor coisa móvel que já possui em garantia de dívida contraída é figura típica de penhor. O fato de a coisa ficar em poder do devedor, como bem observou o relator, não descaracteriza o penhor.

Sucede que, se de penhor se trata, não pode o credor, desde logo, assumir a propriedade do bem dado em garantia, como ocorre na alienação fiduciária. $\mathrm{O}$ art. 765 do Código Civil, proíbe que 
- credor fique com a coisa dada em garantia se a dívida não for paga. Ora, penhor, em que, desde a instituição, já se transfere o domínio da coisa dada em garantia ao credor, antecipa o pacto comissório vedado pelo art. 765 do Código Civil.

Portanto, disfarça-se, nesse tipo de contrato, um penhor que transgride suas normas disciplinadoras.

4. Por outro lado, os poderes que a alienação fiduciária confere ao credor só se justifícam na medida em que o instituto for adequadamente utilizado, não se perdendo de vista a finalidade com que foi criado.

Ampliar a possibilidade de utilização da alienação fiduciária; permitindo que a garantia recaia em bens que o devedor já possuía anteriormente ao financiamento, é retirar-lhe a característica fundamental e admitir que a lei - no caso o art. 765 do Código Civil, seja burlada.

Convém não descurar que a proibição do pacto comissório, originária do direito canônico, tem um conteúdo moral e humanitário que não pode ser olvidado. ${ }^{4}$

Aó credor é legítimo exigir garantia do pagamento. Tal exigência, contudo, não pode ultrapassar os limites traçados pelo ordenamento jurídico.

As instituições financeiras, para os contratos que não se destinam à aquisição de bens ou mercadorias, por impossibilidade da alienação fiduciária, têm à sua disposição as demais figuras jurídicas que atendem a esta finalidade, como a hipoteca e o penhor, na categoria das garantias reais, e as garantias pessoais.

Não significa que a alienacão fiduciária não possa ser cumulada com outras garantias, até mesmo porque nesse sentido na expressa previsão legal (art. 19 do Decreto-lei 413, de 09-01-69). Esta, hipótese, todavia, fica restrita, obviamente, àqueles casos em que for cabível.

\section{CONCLUSÃ O}

É incompatível com o instituto da alienação fiduciária que a garantia recaia sobre coisa diversa da adquirida com o empréstimo garantido.

A cláusula contratual que institui semelhante garantia é ilegal, por caracterizar penhor com antecipação de pacto comissório expressamente vedado pelo art. 765 do Código Civil.

* Para melhor compreensão do presente trabalho e por sua clareza, vale a pena transcrever, na íntegra, o voto do culto Relator: Banco do Estado de Minas Gerais moveu contra a Massa Falida.

\begin{tabular}{llllll}
\hline R. Fac. Direito & Curitiba & a. 25 & n. 25 & p. 119-124, 1989 & 121
\end{tabular}


de Metalúrgica Venax S.A., ação de restituição de $82.000 \mathrm{Kg}$ de chapas de ferro, avaliadas em $\mathrm{Cr} \$ 3.034 .000$, dadas em alienação fiduciária, como garantia de um contrato de repasse de empréstimo externo, no valor de U\$S 80.000,00, de acordo com o art. $1^{\circ}$ do Decreto-Lei 911/69, ou de devolução do respectivo valor, com correção monetária, se inexistentes os bens, nos termos do art. 78 , $\S 2$, da Lei de Falências.

Informou o Síndico que o ferro não foi encontrado.

A sentença, citando doutrina e jurisprudência e considerando inexistentes os bens dados em garantia, julgou improcedente a ação, pois entendeu que o valor original, de Cr\$3.034,00, deveria ser habilitado como crédito quirográfico, com correção monetária se a Massa comportar.

Apelou o autor insistindo na devolução integral do valor corrigido.

O Ministério Público em ambas as instâncias opinou pelo desprovimento do recurso.

É o relatório.

\section{$\mathrm{V} O \mathrm{TO}$}

o Contrato de repasse de empréstimo externo se destinou a "financiamento de capital fixo e/ou de movimento", como se vê da cláusula segunda (fls. 11). Não teve por finalidade a compra do objeto dado em garantia. Aliás, as garantias do contrato foram múltiplas: três promissórias avalizadas dadas em penhor, em valor superior ao do empréstimo; duplicatas caucionadas no valor correspondente a $80 \%$ do mútuo, e alienação fiduciária de $82.000 \mathrm{Kg}$ de chapas de ferro, que já eram de propriedade da devedora.

A alienação fiduciária, como é sabido, se destina a garantir financiamentos empregados na compra de bens móveis, os quais, por isto mesmo, se constituem em objeto da própria alienação. Ao tratar dos sujeitos do contrato de alienação fiduciária, ensina RESTIFFE NETO: "como só transmite quem tem, explica-se porque nas vendas de bens figura como adquirente o consumidor, aquele que é destinatário do financiamento direto (fiduciante), de modo que a compra mercantil (ou civil) é feita à vista, mediante intervenção de financeira, que paga, em nome do comprador, o valor da compra ao vendedor, que se exclui da relação típica que então nasce entre usuário e financiador. O vendedor não transaciona com financiador a dinheiro para este revender a prazo ao consumidor. Há uma compra e venda entre o vendedor e o consumidor e a seguir uma transmissão de caráter peculiar, com o fim.

a. 25

n. 25

p. $119-124,1989$ 
de segurança, entre o financiado (devedor fiduciante) e o financiador (credor fiduciário). Neste segundo momento, quando surge o financiamento, é que se depara o negócio jurídico denominado alienação fiduciária em garantia, que tem sua causa no negócio subjacente, de natureza civil ou mercantil". (Garantia Fiduciária, . $^{a}$ ed., p. 90/1).

Esta Câmara tem negado eficácia, por falta de causa legítima, a contratos de alienação fiduciária para garantia de financiamentos não destinados à compra do objeto dado em garantia. Tais contratos mascaram um penhor, com a agravante de subtrair $o$ bem, desde logo, do domínio do devedor, numa antecipação evidente de pacto comissório vedado em lei, proibido pelo art. 165 do Código Civil.

Note-se que os Bancos que praticam esses contratos cercamse, em suas operações, de um volume enorme de garantias, como ocorre no caso em exame, de tal sorte que o abuso no desvirtuamento da alienação fiduciária de bens do devedor, não adquiridos com o mútuo, para ameaçá-lo ainda com as sanções de depositário infiel, constitui inominável ofensa ao sistema jurídico, além de superafetação intolerável.

Nem se argumente com a impossibilidade de configurar-se na espécie um penhor simulado com fraude à lei, por exigir o penhor a transmissão da posse direta do bem ao credor, ao contrário do que sucede na alienação fiduciária. A tese não é exata porque essa transmissão não é essencial ao instituto do penhor, tanto assim que existe nas espécies de penhor agrícola, pecuário e industrial, nas quais o objeto da garantia permanece na posse direta do devedor, como imperativo da própria continuidade de sua empresa. Neste sentido dispóem de modo expresso o art. 10 da Lei 2.666, de 06-12-55, sobre penhor dos produtos agrícolas, e o art. 28 do Decreto-lei $n^{\circ}$ 413, de 09-01-69, sobre crédito industrial.

Observe-se que esse último diploma, no art. 19, admite como garantia das cédulas de crédito industrial o penhor, a alienação transmissão não é essencial ao instituto do penhor, tanto assim art. 20, a mesma lei no art. 21, em clara remissão ao instituto seguinte, à alienação fiduciária, estatui que "pode-se incluir na garantia os bens adquiridos ou pagos com o financiamento, feita a respectiva averbação nos termos deste Decreto-lei". Mais um dado a comprovar que, em nosso sistema legal, a alienação fiduciória só se admite no tocante $a$ bens adquiridos com o financiamento alcançado pelo credor. Toda vez que o devedor aliena "fiduciaria" mente" ao credor, com garantia, bens que já integravam o patri-. mônio dele, devedor, na verdade está celebrando um pacto comis-:

\begin{tabular}{llllll}
\hline R. Fac. Direito & Curitiba & a. 25 & n. 25 & p. $119-124,1989$ & 123
\end{tabular}


sório ilegal, um penhor simulado em fraude à lei, pois desde logo transfere ao credor o dominio do bem dado em garantia.

Registre-se que a própria Lei do Mercado de Capitais (Lei n? 4.728, de 14-07-65), criadora do instituto da alienação fiduciária, manteve expressamente a proibição do pacto comissório no art. 66, § 60: "É nula a cláusula que autoriza o proprietário fiduciário a ficar com a coisa alienada em garantia, se a divida não for paga em seu vencimento". Não é outra coisa que pretende o autor com o pedido de "restituçãa".

Na lição de CLOVIS BEVILAQUA, "a proibição do pacto comissório funda-se em um motivo de ordem ética. $O$ direito protege o fraco contra o forte, impede que a pressão da necessidade leve o devedor a convencionar o abandono do bem ao credor por quantia irrisória. O Imperador Constantino, impressionado pelas manobras capciosas dos pactos comissórios, cuja aspereza crescia assustadoramente, decretou-lhes a nulidade, e as legislações modernas aceitaram essa condição. O pacto comissório não pode ser estipulado no momento de ser dada a garantia real, nem posteriormente" (Código Civil Comentado, com. ao art. 765).

No caso, o abuso do instituto da alienação fiduciária, para obter ainda, sob forma de pressão contra o devedor, a ameaça da prisão como depositário infiel do próprio bem que já era dele, que não foi adquirido com o mútuo, pois se trata, na verdade, de simples mútuo, se transforma em agravante à conduta capciosa do credor, que passa a raiar pelo crime de extorsão indireta, assim tipificado pelo art. 160 do Código Penal: Exigir ou receber, como garantia de divida, abusando da situação de alguém, documento que pode dar causa a procedimento criminal contra a vitima ou contra terceiro. Pena - reclusão de um a três anos, e multa".

Nestas condições, tratando-se, como se trata, de cláusula em fraude à lei, a simular, repito, um penhor com pacto comissório antecipado, padece do vício de nulidade a alienação fiduciária de bens do devedor, nâo adquiridos com o financiamento do devedor.

Por estes fundamentos, na esteira da jurisprudência já consolidada desta Câmara, nego provimento à apelação.

\section{NOT A S}

(1) Exposição de Motivos com que o Ministro Delfim Neto encaminhou o Projeto que resultou o Decreto-Lei 911/69, publicado no jornal "Folha de São Paulo", edição de 03-10-69, p. 12.

(2) Apud Moreira Alves, José Carlos, Da alienação fiduciária em garantia, São Paulo, Saraiva, 1973, p. 11.

(3) Contratos e obrigações comerciais, 6.² ed., Rio de Janeiro, Forense, 1981, p. 233.

(4) Restiffe Neto, Paulo, Garantia fiduciária, São Paulo, R.R., 1975, pp. 183-187. 